\title{
Leitura, recepção midiática e produção de sentido
}

Eneus Trindade

Pós-doutor em Antropologia Visual pela Universidade Aberta de Lisboa. Doutor e mestre em Ciências da Comunicação pela Universidade de São Paulo - USP, onde é professor da Escola de Comunicações e Artes, e membro do Grupo de Estudos Semióticos em Comunicação, Cultura e Consumo na ECA/USP*

E-mail: eneustrindade@usp.br

Sérgio Annibal

Doutor em Educação e mestre em Estudos Literários pela Universidade Estadual de São Paulo - UNESP. Professor da Rede Estadual de Ensino Paulista e membro do Grupo de Estudos e Pesquisas sobre Linguagem, Ensino e Narrativa de Professores (GEPLENP) na UNESP**. E-mail: sergioannibal@gmail.com

Resumo: Pretendemos discutir neste artigo as relações de produção de sentido entre os conceitos de recepção, leitura e leitor. Para tanto, haverá considerações sobre os estudos da recepção e da história da leitura no mundo ocidental, considerando a interface com diferentes mídias. Aliados a essas discussões, procuraremos evidenciar o processo de produção de sentido por meio das discussões já referidas e da elaboração de categorias de leitores. Como resultado, tentaremos demonstrar que os processos de leitura e de recepção midiáticas têm sua coerência teórica no campo epistêmico da representação.

Palavras-chave: leitura, educação, recepção, produção de sentido da comunicação.
Abstract: We aim to make a discussion about production of sense among the concepts of reception, reading and reader. Moreover, there are considerations on the studies of reception and history of the reading in the occidental world, considering the interfaces with different midias. Together with these points we elaborate some categories of readers. Ours results try to demonstrate the process of reading and reception of midias have coherence in the epistemic field of representation.

Keywords: reading, education, reception, production of sense in communication.

Os estudos da leitura trazem a discussão de que o ato de ler inclui uma espécie de recepção e a capacidade de estabelecer inter-relações com diversos gêneros textuais. Com isso, ficam-nos evidentes suas implicações na produção de sentido para a formação de práticas culturais, que visam à apreensão de diversos signos socioculturais no contexto das visões de mundo em que os indivíduos se inserem. Todavia, procuraremos nos debruçar sobre os processos de leitura e de recepção separadamente.

Recebido: 28.05 .2008

Aprovado: 04.11.2009

Disponível em: <http://lattes.cnpq. br/1421349592402127>.

** Disponível em: <http://lattes.cnpq. br/9747306063454703>. 
1. ARENA, D. B. Considerações sobre o estatuto do leitor crítico. In: BARBOSA, R. L. L. (Org.). Formação de educadores: artes e técnicas - ciências e políticas. São Paulo: Editora Unesp, 2006. p. 414.

2. Sprenger-Charoll, apud FOUCAMBERT, J. A criança, o professor e a leitura. Porto Alegre: Artmed, 1998. p. 118

3. Ibid., p. 119

4. CHARTIER, R. A aventura do livro do leitor ao navegador. São Paulo: Editora Unesp, 1997; Os desafios da escrita, cit., 2002

5. CHARTIER, R.; CAVALLO, G. (Org.). História da leitura no mundo ocidental. São Paulo: Ática, 2002.

6. MANGUEL, A. Uma história da leitura. São Paulo: Cia. das Letras, 1997.

7. SMITH, F. Compreendendo a leitura: uma análise psicolinguística da leitura e do aprender a ler. Porto Alegre: Artmed, 2003
Quem estuda leitura preocupa-se com uma performance do ler, investiga as práticas dos leitores em confronto com os modos de ler moldados pelos vários suportes de leituras ao longo da história das culturas, interessa-se pela aquisição de competências interpretativas pela leitura, bem como estuda os processos cognitivos e de aquisição do conhecimento em uma dada língua. Já a recepção engloba a decodificação do verbal e a interpretação de um conjunto de manifestações de linguagens que compõem o universo cultural do cotidiano que se encontra midiatizado, constituído de saberes comuns partilhados pelas várias culturas.

Sobre a leitura, Arena ${ }^{1}$, apoiado em Foucambert ${ }^{2}$, que recupera conceitos de Sprenger-Charoll, registra que os processos de leitura se dão de dois modos: os ascendentes ou botton-ups, que consideram as partículas isoladas do sistema linguístico, termo a termo, tais como letras, palavras e frases para a formação do texto, e sua leitura; e os descendentes, ou top-downs, que atuam no âmbito do sentido, promovendo o confronto com as demais partes do texto, seu suporte e seu contexto de interpretação. A releitura dos conceitos de Sprenger-Charoll por Foucambert ${ }^{3}$, como é indicado por Arena, mostra que a proposta mais eficiente de compreensão da leitura acontece por um modelo derivado da conexão desses dois movimentos, botton-ups e top-downs, que traz mais eficiência para o entendimento da leitura, isto é, o interacionista: que justapõem os dois procedimentos já enunciados.

Para análise do material midiático isso é fundamental, pois, muitas vezes, ele é representado como algo menor diante das outras manifestações escritas, além do fato de ser analisado de acordo com paradigmas importados de outros suportes, como o texto literário, por exemplo. Sendo assim, a recepção e a produção de sentido decorrentes desse material podem ser entendidas como mecanismos relacionados, podendo sofrer reducionismos se a clareza dos estatutos de leitor e de receptor não acompanhar o movimento mutante da tessitura social em que esses produtos culturais estão inseridos.

Portanto, cabe buscar entender o que é a codificação e a decodificação no âmbito dos códigos verbais e não verbais para depois compreendermos o papel da produção de sentido nessas duas dimensões semióticas e oferecermos outros aspectos das semelhanças e das divergências entre leitura e recepção.

Mesmo em áreas como a Educação e as Letras, o conceito de leitura vem ganhando outros formatos, deixando mais complexa a concepção acerca da leitura e do leitor. Esse novo olhar sobre a leitura e os novos estatutos de leitor ultrapassam a compreensão alicerçada na codificação e na decodificação de um signo. Tal postura em relação a essas instâncias receptoras (leitura e leitor) está bem explanada em Chartier ${ }^{4}$, Chartier e Cavallo ${ }^{5}$, Manguel ${ }^{6}$ e Smith $^{7}$, por exemplo.

A leitura é, sem dúvida, um tipo de recepção pautada nos códigos verbais. Porém, é preciso observar que as complexas formas de combinação do signo verbal a outros signos não verbais, por meio da diversificação dos suportes midiáticos, criam rupturas com a noção tradicional de produção de sentido, 
pautada nos estudos da cognição e da semiótica, fundamentados na ideia de que as produções de sentido são decorrentes da pura decodificação.

Atualmente, podemos defender a ideia de que as produções de sentido precedem ou apresentam relativa independência em relação aos processos de decodificação, como percebemos em Foucambert ${ }^{8}$ e em Smith $^{9}$, pois, para o primeiro, as leituras descendentes dependem da práxis cultural que caracteriza o meio sociocultural onde o indivíduo está inserido nas suas ações e contextos de leituras; já o segundo também defende a ruptura com o binômio codificação/decodificação, assinalando que a prática cultural exerce papel essencial na construção de sentido das leituras. De outro ponto de vista, Stuart Hall ${ }^{10}$, ao estudar a recepção, já aponta a importância da sobredeterminação dessa práxis cultural sobre processos de decodificação da recepção.

À medida que os processos envolvidos na leitura se desprendem do conceito restrito à decodificação, verificamos grande possibilidade de uma autonomia do leitor em relação ao material verbal e não verbal, além de contribuir para a efetivação que a leitura suscita em estabelecer relações discursivas do indivíduo com seu meio, a partir dos textos.

Ademais, a leitura e a recepção não são conceitos equivalentes, mas trazem aspectos comuns, no sentido de que tudo aquilo que se lê está inserido em um processo comunicativo que implica a recepção; porém, nem tudo aquilo que vem de um processo comunicativo é necessariamente uma mensagem para a leitura verbal. Mas, certamente, essa mensagem é um discurso carregado de sentidos passíveis de interpretações, causador de trocas e, como assinala Arena ${ }^{11}$, provoca transformações em ambas as partes: no objeto lido e no leitor deste objeto.

A impressão que fica é a de que nas mídias existe um modelo de leitura literária que migrou e interagiu com outras linguagens dos meios de comunicação, criando modalidades de leituras midiáticas, de acordo com aquilo que já começamos a enunciar neste texto. No entanto, tais leituras precisam se somar a um conjunto metodológico maior que busca dar conta das interpretações dessas mensagens, considerando as suas respectivas complexidades semióticas para a compreensão da produção de sentido.

\section{LEITURAS: POSSIBILIDADES LITERÁRIAS E MIDIÁTICAS}

Quando nos referimos a essas modalidades de leitura, temos de nos reportar à postura do leitor e às transformações no suporte no decorrer da história da leitura, como se pode constatar nas discussões de Manguel, Chartier e Chartier e Cavallo, já citados. Esses autores abordam, com seus distintos tratamentos sobre o assunto, o lugar do sujeito-leitor diante do escrito, dando-nos um panorama da reação que ele teve diante do pergaminho, do códice, do livro organizado em parágrafos, revistas, jornais, e do texto digital.

Além disso, procuram discutir as modificações na tipologia textual e no entendimento sobre leituras ocorridas por parte dos leitores ao longo da história, impulsionados a refletir sobre a postura desse leitor contemporâneo, levando em

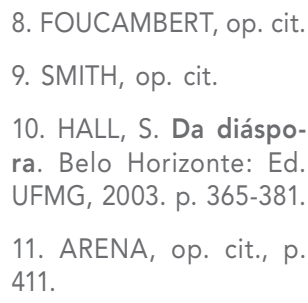


12. CHARTIER, op. cit. (1997, 2002).

13. SANTAELLA, L. Três tipos de leitores: o contemplativo, o movente e o imersivo. Líbero: revista acadêmica de pós-graduação da Faculdade Cásper Líbero. São Paulo, ano V, v. 5, n. 9-10, p. $30-9,2002$

14. ARENA, op. cit.

15. Ibid. consideração os atributos que determinam a proficiência nessa tecnologia, diante do material escrito, que deixa de ser protagonista no formato tradicional do livro e se transfigura em vários outros suportes, até transfigurar-se no não verbal.

Para isso, resgatamos e elaboramos algumas categorias para melhor compreender esses perfis de leitores. Trata-se de experimentações categóricas, provavelmente perecíveis no tempo e no espaço; todavia, nos oferecem a oportunidade de refletir sobre a temática e contribuir para a ampliação das discussões acerca dos suportes que estão diariamente surgindo e alterando nossa mediação com o mundo. Como Chartier ${ }^{12}$ nos faz perceber, o conhecimento sobre a história da leitura contribui para entendermos melhor as práticas leitoras e suas transformações e até possíveis interpretações de sua função social e cultural na sociedade. Mas, de qualquer forma, vamos aos nossos leitores hipotéticos ou, quem sabe, constatados.

A elaboração de categorias sobre a leitura vem sendo utilizada com bastante frequência na abordagem do assunto, como nos textos de Santaella ${ }^{13}$ e de Arena $^{14}$, por exemplo. No primeiro caso, encontramos três características distintas de leitor: o contemplativo, relacionado basicamente ao material impresso; o movente, ligado aos diferentes signos da propaganda, das mídias audiovisuais e impressas que compõem a vida das cidades; e o imersivo, que se debruça sobre o universo relacional e povoado de interfaces do ciberespaço. Os três tipos de leitores trazem diferenças vinculadas à postura leitora e aos aspectos cognitivos, como assinala a autora.

Arena ${ }^{15}$ traz um texto que aborda outras categorias de leitores: críticos e sênior. Tais categorias se distinguem de acordo com as demandas sociais e culturais de um determinado tempo, espaço e função social. O leitor pode ser chamado de crítico se atende aos estatutos específicos de certa área do conhecimento, como é o caso do leitor literário. Já o sênior, apresenta uma flexibilidade relacionada aos gêneros textuais; não basta ser um excelente crítico em um gênero específico, deve-se conhecer o máximo possível do universo da leitura. É uma espécie de leitor in potencia e polivalente, munido de várias habilidades, que podem variar de acordo com seu prazer e sua necessidade. Portanto, esses leitores não são claramente classificados em atributos distintos; variam de acordo com o meio sociocultural em que estão inseridos.

Em relação às categorias propostas neste texto, o leitor canônico versus o leitor digital nos suscita questionamentos a uma espécie de gradação que se faz presente na tomada da leitura madura. É como se uma leitura fosse mais importante do que a outra e não complementares. Aquele que advém de uma cultura canônica e conservadora parece apresentar dificuldades de administrar o escrito em outros suportes, tornando-se proficiente em um tipo de escrita e de leitura e não tanto em outro. A problemática desse fato está na visão bipartida que esse sujeito constitui, concebendo a leitura literária passível de grandes abstrações intelectuais e a digital, como um texto de menor grandeza, ou vice-versa. Sendo assim, a visão dicotômica desse indivíduo provavelmente o impedirá de ver o mundo em completude, podendo prejudicar a apreensão 
complexa da realidade. Logo, o texto literário e o texto digital devem ser percebidos como integrantes de um meio social híbrido e mutante.

O leitor enformado versus o leitor informado nos conduz a uma diferenciação de repertórios: o leitor enformado tem uma formação limitada em um único gênero textual ou tem iniciação rudimentar em diversos gêneros discursivos do cotidiano, e sua limitação também se manifesta em gradações conforme as competências interpretativas que lhe são exigidas no dia a dia. Provavelmente tal leitor terá dificuldades em concretizar um olhar amplo do mundo que faz parte, podendo constatar um universo restrito às paredes das formas sociais que determinado sistema lhe impôs, daí a metáfora da fôrma e a concepção do leitor enformado. Já o informado tem a possibilidade de desbravar os vários códigos verbais e não verbais, escritos em variados suportes, e descortinar-se e descortinar o outro por meio de seus mecanismos de leitor experiente.

Finalmente, temos o leitor receptor em movimento versus o leitor receptor operacional. O primeiro nos obriga a uma referência a Adam Shaff ${ }^{16}$, no que tange à questão da linguagem como matéria-prima para o desenvolvimento intelectual humano, pois esse tipo de leitor parece absorver o signo transfigurado em vários suportes e ressignificá-lo, estabelecendo várias interfaces no meio em que vive e concretizando o sentido de leitura na sua plenitude. Já o leitor receptor operacional seria aquele que parece apresentar déficits nesse processo de ressignificação, gerando uma atmosfera preocupante em relação ao desenvolvimento da performance desse sujeito em um espaço social que exige uma desenvoltura para com os signos. Certamente essa operacionalidade da leitura e da recepção está condicionada às gradações dos leitores enformados na vida social.

Procuramos, por meio das categorias concebidas, discutir nossa preocupação acerca da reação do leitor contemporâneo diante das transformações sofridas na tecnologia de gestão do escrito. Transformações estas que parecem interferir na produção da leitura e da escrita e, consequentemente, na produção de sentido. Talvez a novidade resida no fato de estarmos inquietos a respeito da interação existente entre esse leitor contemporâneo e as novas tecnologias referentes às mídias. Mesmo depois de arriscarmos algumas hipóteses de categorias, resta-nos ainda algumas inquietações em relação a esse leitor-receptor, principalmente no que tange à sua regulação sociocultural e à consciência de sua função diante da própria existência.

Por conseguinte, a leitura e suas possibilidades, seja ela literária ou midiática, nos oferece a impressão de paradigmas e de estatutos. Se eles não forem discutidos e refletidos no âmbito de um contexto abrangente e sob uma perspectiva sociocultural, perdem seu sentido e podem se constituir em um signo anacrônico e suscetível de interpretações equivocadas.

\section{AS PRÁTICAS DE RECEPÇÃO MIDIÁTICAS}

Compreendemos que as práticas de recepção midiáticas incluem as leituras verbais em seus diversos suportes midiáticos e as construções sígnicas em códigos verbais e extralinguísticos. A produção de sentido das mídias parece ser
16. SHAFF, A. Linguagem e pensamento. Coimbra: Ed. Almedina, 1971. 
17. SOUZA, M. W. Recepção midiática: linguagem de pertencimento. Revista Latinoamericana de Ciências de La Comunicacíon. São Paulo: ALAIC, ano 2, n. 2. jan./ jun. 2005, p. 15.

18. HALL, op. cit., p. 369

19. MARTÍN-BARBERO, J. M. Dos meios às mediações: comunicação, cultura e hegemonia. 2. ed. Rio de Janeiro: ED. UFRJ, 2001.

20. BOURDIEU, P. O poder simbólico. Rio de Janeiro: Bertrand Brasil/ Diefel, 1989.

21. CHARAUDEAU, P. Discurso das mídias. Tradução Ângela M. S. Corrêa. São Paulo: Ed. Contexto, 2006.

22. FAIRCLOUGH, N. Analyzing discourse: textual analysis for social research (Analisar discurso: análise textual pela pesquisa social). London: Ed. Routledge.2003.

23. TRINDADE, E. Diretrizes para uma teoria da enunciação da recepção publicitária. In: Revista Brasileira de Ciências da Comunicação. São Paulo: Intercom, v. 31, n. 2, p. $35-54,2008$

24. Sobre o comentário referente às teorias da enunciação em Bakhtin e Benveniste ver: FLORES; TEIXEIRA. Introdução à linguística da enunciação. São Paulo: Contexto, 2005. mais ampla que na leitura e seu estudo e compreensão dependem dos vínculos ou dos sentidos de pertencimento e pertinência de determinados fenômenos à vida cotidiana. Para Souza, "os meios de comunicação lidam com um comum social de informações, valores e necessidades que constituem a representação do que passa a ser buscado na concretude de práticas cotidianas"17.

As práticas cotidianas são práticas culturais, cuja práxis se constitui como modo de incorporação e naturalização dos códigos pertinentes às culturas, como já diagnosticou Stuart Hall ${ }^{18}$ em suas proposições sobre a recepção. Percebe-se também que, além dos Estudos Culturais ingleses, podem ser identificados outros lugares de convergência para o entendimento da relação dos meios de comunicação com o nosso cotidiano, incluindo e indo além da leitura, quando são estabelecidos diálogos com a teoria das mediações latino-americanas fundadas nas propostas de Martín-Barbero ${ }^{19}$, com a teoria da produção social simbólica em Bourdieu ${ }^{20}$, com os estudos recentes da semiótica, da pragmática e da análise de discurso de linha francesa, como ilustra a produção de Patrick Charaudeau $^{21}$, e da Análise do Discurso Crítico, de Fairclough ${ }^{22}$.

Todos os direcionamentos teóricos apontados aqui trazem a perspectiva de entendimento de que as ações sociais e culturais são ações de linguagem, pois suas objetivações nas realidades constituem representações simbólicas, cujos códigos podem manifestar uma natureza verbal ou não verbal. As ações humanas são atos de linguagem, que se revertem a práticas sociais e culturais carregadas das visões de mundo das culturas com suas respectivas maneiras de manifestar seus sentidos.

A partir do pressuposto colocado, torna-se necessário identificar critérios de pertinência comuns entre o estudo da mediação sígnica dos discursos, para a formulação dos sentidos do mundo, e as produções de sentido dos indivíduos na vida cotidiana. Tais critérios podem ganhar materialidade pela contribuição das teorias da enunciação de base linguística em Bakhtin e em Benveniste, como discutimos em outra oportunidade ${ }^{23}$. O primeiro autor discute a dinâmica dialógica constitutiva da linguagem, o que nos permite entender que existem várias instâncias e conflitos das e nas construções de sentidos em um processo de enunciação, que é em si um processo de comunicação. O segundo entende a enunciação como a construção do que é dito e que se dá pela representação de mecanismos de pessoa, espaços e tempos marcados ou subtendidos nos discursos, o que pressupõem nessas representações o fato de que todo discurso resulta da interação (comunicação) entre sujeitos em um dado tempo e em um dado espaço. O discurso reflete seu contexto ${ }^{24}$.

Além do campo verbal, ocorrem também interações subjetivas (pessoas, instituições), em um dado tempo e em um dado espaço, cujos mecanismos de representação não são iguais aos verbais; porém, tal conjunto enunciativo tem uma lógica codificadora que é sígnica, construtora de sentidos pertinentes às culturas.

Disso surge outro problema: os teóricos de origem linguística, embora seminais, buscam dar conta dos fenômenos verbais. Mas e o aspecto não verbal dos processos midiáticos na vida das pessoas? É nesse momento que lançamos 
mão das contribuições da antropologia, associada às teorias do discurso, e da semiótica, pois a complexa produção simbólica de sentido estimulada por códigos não verbais encontra possibilidades nessa interface de estudo.

As contribuições da etnografia partem inicialmente da necessidade de descrever os espaços, tempos e contextos em que os sujeitos se relacionam com as mídias em seus cotidianos. A partir da observação e de outros procedimentos metodológicos é possível entender os comportamentos cotidianos que vinculam as mídias às práticas culturais diárias; e os estudos etnográficos, como os da etnografia das audiências, podem encontrar descrições de realidades, no que tange às estruturas sociais complexas e que na comunicação configuram uma espécie de estudo da enunciação dos discursos de uma dada cultura, ou seja, de como elas se fazem dizer, manifestam-se.

A chamada etnografia das audiências absorve métodos antropológicos e etnológicos clássicos, como a observação participante, conversas informais, histórias de vida, diários de observação, e possibilita a análise documental dos produtos midiáticos para criar nexos entre os valores manifestados nos produtos culturais e os sentidos da vida cultural etnograficamente registrados, como se verifica em La Pastina ${ }^{25}$.

Cada mídia demanda uma observação etnográfica que considere suas especificidades. Somam-se a isso as reflexões de Clifford Geertz ${ }^{26}$, que influenciou outros antropólogos dedicados aos estudos midiáticos com suas ideias sobre a etnografia; e a combinação dos estudos discursivos e semióticos propiciaria ricas possibilidades para os estudos antropológicos. Isso fortalece nossa opção teórica de aglutinar os estudos dos discursos e da leitura aos estudos da recepção, no desafio de entender a produção de sentido da recepção midiática no campo da comunicação.

A partir dessa perspectiva, entendemos que as análises etnográficas, ao superarem a descrição das realidades estudadas, podem culminar nas análises etnológicas (da enunciação cultural), que implicam uma movimentação interdisciplinar a qual busca a compreensão dos vínculos dos produtos midiáticos com a vida social, resultantes dos estudos sobre a produção de sentido, como mediação sígnica que nos permite ter acesso às várias realidades da vida humana.

\section{OS CAMINHOS DO DISCURSO: A PRODUÇÃO DE SENTIDO COMO MODO DE CONHECER}

A compreensão das diversas formas de produção de sentido ante as mudanças tecnológicas e as ressignificações das relações humanas necessita de posturas investigativas interdisciplinares que considerem a natureza dos sistemas representativos envolvidos nas comunicações, geradoras de leituras verbais e práticas de recepção que se transformam em práticas sociais e culturais.

As produções de sentido resultantes e manifestantes de tais práticas dependem dos contextos a serem analisados, na perspectiva da influência da
25. LA PASTINA, A. Etnografia de audiência: uma estratégia de envolvimento. In: JACKS, N. et al. O que sabemos sobre as audiências. Porto Alegre: ALAIC GT - Estudios de Recepción/ Ed. Armazém Digital, 2006. p. 27-43.

26. GEERTZ, C. Interpretations of cultures (Interpretações das culturas). New York: Basic Books, 1973. 
vida familiar, do trabalho, da escola, da religião, da política, do repertório cultural, do meio ambiente, da economia, das características socioculturais em que os indivíduos vivem as suas realidades, considerando-se as inúmeras situações sociais que a vida contemporânea lhes impõe, como propõem os autores latino-americanos da teoria das mediações.

Trata-se de uma complexa forma de empreender investigações, tendo como critério de pertinência metodológica o processo linguageiro, a comunicação como enunciação, que não é apenas canal/meio e mensagem, mas modo e processo de representação e de regulação das diversas relações sociais e das identidades que os indivíduos e instituições, na complexa rede social e cultural, passam a assumir. Ou seja: o modo como as culturas se fazem dizer, representar.

\section{REFERÊNCIAS BIBLIOGRÁFICAS}

ARENA, D. B. Considerações sobre o estatuto do leitor crítico. In: BARBOSA, R. L. L. (Org.). Formação de educadores: artes e técnicas - ciências e políticas. São Paulo: Editora Unesp, 2006.

BOURDIEU, P. O poder simbólico. Rio de Janeiro: Bertrand Brasil/Diefel, 1989.

CHARAUDEAU, P. Discurso das mídias. Tradução Ângela M. S. Corrêa. São Paulo: Ed. Contexto. 2006.

CHARTIER, R. Os desafios da escrita. São Paulo: Editora Unesp, 2002.

. A aventura do livro do leitor ao navegador. São Paulo: Editora Unesp, 1997.

CHARTIER, R.; CAVALLO, G. (Org.). História da leitura no mundo ocidental. São Paulo: Ática, 2002.

FAIRCLOUGH, N. Analyzing discourse: textual analysis for social research (Analisar discurso: análise textual pela pesquisa social). London: Ed. Routledge, 2003.

FLORES; TEIXEIRA. Introdução à linguística da enunciação. São Paulo: Contexto, 2005.

FOUCAMBERT, J. A criança, o professor e a leitura. Porto Alegre: Artmed, 1998.

GEERTZ, C. Interpretations of cultures (Interpretações das culturas). New York: Basic Books, 1973.

HALL, S. Da diáspora. Belo Horizonte: Ed. UFMG, 2003.

LA PASTINA, A. Etnografia de audiência: uma estratégia de envolvimento. In: JACKS, N. et al. O que sabemos sobre as audiências. Porto Alegre: ALAIC GT Estudios de Recepción/Ed. Armazém Digital, 2006.

MANGUEL, A. Uma história da leitura. São Paulo: Cia. das Letras, 1997. 
Leitura, recepção midiática e produção de sentido - Eneus Trindade e Sérgio Annibal

MARTÍN-BARBERO, J. M. Dos meios às mediações: comunicação, cultura e hegemonia. 2. ed. Rio de Janeiro: ED. UFRJ, 2001.

SANTAELLA, L. Três tipos de leitores: o contemplativo, o movente e o imersivo. In: Líbero: revista acadêmica de pós-graduação da Faculdade Cásper Líbero. São Paulo, ano V, v. 5, n. 9-10, 2002.

SHAFF, A. Linguagem e pensamento. Coimbra: Ed. Almedina,1971.

SMITH, F. Compreendendo a leitura: uma análise psicolinguística da leitura e do aprender a ler. Porto Alegre: Artmed, 2003.

SOUZA, M. W. Recepção midiática: linguagem de pertencimento. Revista Latinoamericana de Ciências de La Comunicacíon. São Paulo: ALAIC, ano 2, n. 2. jan./jun. 2005.

SPRENGER-CHAROLL, apud FOUCAMBERT, J. A criança, o professor e a leitura. Porto Alegre: Artmed, 1998.

TRINDADE, E. Diretrizes para uma teoria da enunciação da recepção publicitária. Revista Brasileira de Ciências da Comunicação. São Paulo: Intercom, v. 31, n. 2, 2008. 


\section{बृ
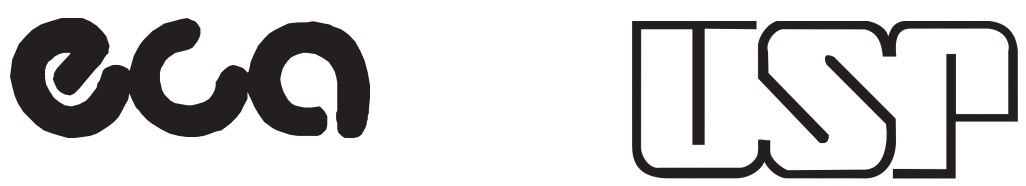

\section{ESPECIALIZAÇÃO LATO SENSU Gestão da Comunicação}

gestor da comunicação planeja e executa projetos de comunicação em empresas privadas, instituições públicas ou movimentos comunitários, nas áreas educacional, empresarial ou artístico-cultural.

- Capacitação do aluno para elaborar, implantar, avaliar e reestruturar projetos de comunicação/cultura.

- Integração teórico-prática da área de comunicação com o mercado de trabalho.

- Formação humanística e profissional sólidas, baseada na inter-relação comunicação/cultura/artes.

- Qualificação do profissional, preparando-o para compreender o mercado emergente, em constante transformação, e agir sobre ele.
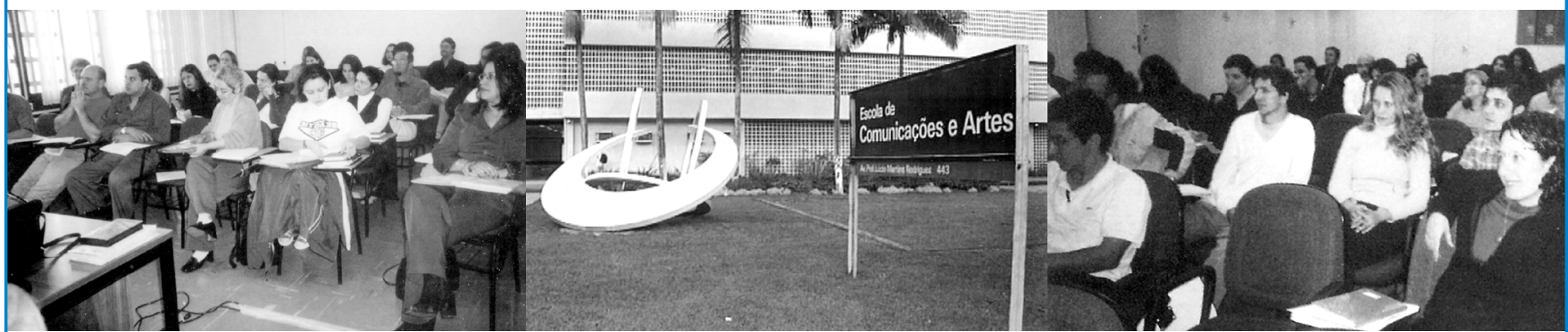

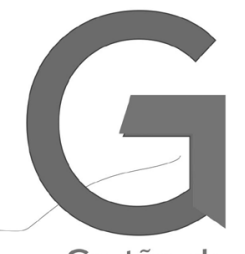

Gestão da

Comunicação Especializaçăo lato sensu

CCA - ECA - USP
Duração: três semestres

Pré-requisito: formação superior (qualquer área)

Seleção: prova escrita, entrevista e plano de estudo

Ingresso semestral: $1^{\circ}$ semestre: turma com aulas às sextas-feiras e aos sábados $2^{\circ}$ semestre: turma com aulas de segunda a quarta-feira

Informações: ECA/USP: 3091-4063/4341/4326 - e-mail: gestcom@edu.usp.br www.eca.usp.br/gestcom 